\title{
Clinical Features of Accidental Hypothermia, With Some Observations on Thyroid Function
}

\author{
A. J. ROSIN*, M.B., M.R.C.P., M.R.C.P.GLASG., A. N. EXTON-SMITH*, M.A., M.D., M.R.C.P.
}

Brit. med F., 1964, 1, 16-19

Failure of temperature regulation resulting in hypothermia can occur in a number of diseases. There is now increasing awareness of one of the commonest types called accidental hypothermia. This condition occurs spontaneously, usually in a cold environment, and is often associated with an acute systemic disturbance without an apparent primary pathological lesion of the temperature-regulating centre in the brain. Old people seem especially at risk to this condition in winter-time. The diagnosis is often made on suspicion, suggested by the cold state of the body and the environmental circumstance, but it may be overlooked, with grave consequences to the patient.

Duguid et al. (1961) described a series of 22 patients with hypothermia treated in hospital over a period of three years, and analysed the clinical and pathological features. The poor prognosis was shown in some cases to be due to widespread vascular occlusive damage in the viscera. That the condition is not rare is indicated in a report (Prescott et al., 1962) in which accidental hypothermia was present in $2.5 \%$ of acute medical admissions to one hospital in the winter.

In a group of 32 patients with hypothermia whom we have seen, an attempt has been made to distinguish the causes and results of hypothermia. This paper describes the clinical features and diseases associated with the fall in temperature. In some of the patients who were known to have been euthyroid studies were made of some tests of thyroid function, as there is evidence of disturbance of radioiodine uptake in severe hypothermia (Verzár et al., 1953).

\section{Clinical Features}

The series consisted of 25 women and 7 men. Sixteen of them were seen last winter. Their ages ranged from 60 to 92 years, with the exception of one aged 39 who had barbiturate poisoning. Rectal temperatures under $95^{\circ} \mathrm{F}$. $\left(35^{\circ} \mathrm{C}\right.$.) recorded with a low-reading thermometer were regarded as abnormal. The immediate environment from which the patients came is shown in Table I.

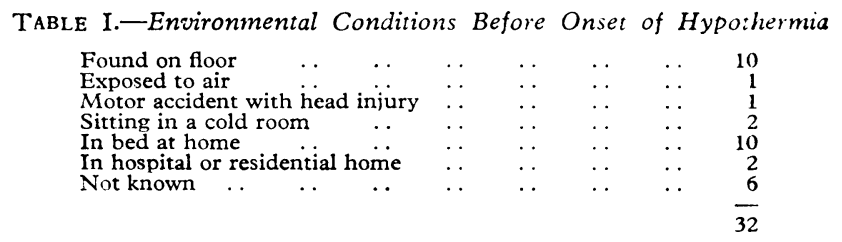

Although some who were in bed at home were undoubtedly in inadequately heated rooms, one such patient had an electric heater in the room and one was in bed fully clothed. The following description is based on an analysis of the important clinical features of the 32 patients.

State of Consciousness.-At temperatures above $90^{\circ} \mathrm{F}$. $\left(32.2^{\circ}\right.$ C. $)$ it appeared that coma or stupor was related to the primary condition, such as cerebral damage or fulminating

* Whittington Hospital, I,ondon. infection, rather than to hypothermia. Temperatures below $90^{\circ} \mathrm{F} .\left(32.2^{\circ} \mathrm{C}\right.$. $)$ were usually associated with at least clouding of consciousness whatever the primary clinical condition, and often with restless stupor.

Appearance.-There was often pallor, due to vasoconstriction of skin vessels, and cyanosis frequently occurred, especially when there was concurrent bronchopneumonia. Oedema of the facial skin may give an appearance similar to that of hypothyroidism (Duguid et al., 1961), as does the slow cerebration and the croaking voice which were sometimes evident. The body was characteristically cold, not only in the extremities but also in the covered portions, such as axillae and groins.

Central Nervous System.-At temperatures below $90^{\circ} \mathrm{F}$. $\left(32.2^{\circ}\right.$ C. $)$ it may be difficult to differentiate primary cerebral disease from transient dysfunction due to hypothermia. Muscle tone is usually increased and rigidity is of ten present below this temperature, at which the shivering response to cold is usually abolished. Deep reflexes were sluggish in 12 patients and abnormally brisk in 7, in whom there was evidence of a cerebrovascular accident. Plantar responses were often extensor, and sometimes reverted to flexor as the patient recovered consciousness. Delayed relaxation of the reflex such as occurs in myxoedema was a feature in moderately severe degrees of hypothermia. An intermittent flapping involuntary tremor was seen in some stuporous patients at temperatures below $90^{\circ} \mathrm{F}$. $\left(32.2^{\circ}\right.$ C.). Neck stiffness was elicited in five cases, although there was no subarachnoid haemorrhage or infection. The size of the pupils varied between wide dilatation and pin-point constriction, and their reactions were usually sluggish.

Cardiovascular System.-Auricular fibrillation or sinus bradycardia were the most common types of rhythm, especially at temperatures below $90^{\circ} \mathrm{F}$. $\left(32.2^{\circ} \mathrm{C}\right.$.). A heart rate of below $50 / \mathrm{min}$. was recorded in 11 patients, in 7 of whom it was less than $40 / \mathrm{min}$. This is in keeping with findings in experimental hypothermic animals. Blood-pressure was often low without a compensatory tachycardia. Gangrene of the toes occurred in two patients owing to the poor peripheral blood flow and the intense vasoconstriction.

Respiratory System.-Slow and sighing respirations are characteristic of hypothermia, but in the presence of severe pneumonia rapid or stertorous breathing was noted and sometimes Cheyne-Stokes respiration was present. Bronchopneumonia appeared to be a common precipitating factor and an equally common result of the hypothermic state.

Alimentary System.-As pancreatitis is now known to be an accompaniment and probably a result of hypothermia we tried to detect its presence. In contrast to the classical picture of severe pain and shock the only positive findings which were noted in three patients were vague tenderness in the epigastrium and mild localized resistance of the abdominal muscles. A raised serum amylase was found in 9 out of 11 cases tested, including the above three, indicating that a disturbance of pancreatic function is not uncommon. The serum amylase may revert to normal, as shown in one patient by serial readings of 660,700 , and 181 units per $100 \mathrm{ml}$. on the first, second, and eighth days; the pancreas at necropsy showed oedema and some fat necrosis. 


\section{Investigations}

Haematology.-In some cases there was a depression of the white-cell count, associated with overwhelming infection. One patient with fulminating pneumonia and cystitis had a leucocyte count of $1,500 / \mathrm{cmm}$. (mainly neutrophil polymorphs), and a myxoedematous woman who had 800 white cells/c.mm. died 24 hours after admission from bronchopneumonia. On the other hand, eventual recovery occurred in a confused woman with a temperature of $85^{\circ} \mathrm{F} .\left(29.4^{\circ} \mathrm{C}\right.$. $)$ and a white count of $3,000 /$ c.mm., and in a confused woman with a temperature of $76^{\circ}$ F. $\left(24.4^{\circ}\right.$ C. $)$ and a white count of $15,100 / \mathrm{c} . \mathrm{mm}$. $(46 \%$ metamyelocytes). Although depression of the platelet count occurs in hypothermia in infants this was not observed in the present series.

Biochemistry.-No consistent changes were found in the serum electrolytes. In some cases the serum sodium was high and was probably due to previous water depletion. The serum level of the glutamic oxaloacetic transaminase (S.G.O.T.) may be of value in suggesting the presence of myocardial infarction, although it is known that micro-infarcts of muscle may also cause a rise of S.G.O.T.

Electrocardiograph.-Bradycardia, slow auricular fibrillation, and muscle tremors are common at temperatures under $90^{\circ} \mathrm{F}$. $\left(32.2^{\circ}\right.$ C.). J waves (Osborne, 1953 ; Emslie-Smith, 1958) are a characteristic association, and were present in nine cases. Though not necessarily related to depth of hypothermia they tend to disappear as the temperature rises above $90^{\circ} \mathrm{F} .\left(32.2^{\circ}\right.$ C.). $T$ waves are often flat or inverted and auriculoventricular and intraventricular conduction is usually slowed.

\section{Thyroid Function}

Hypothermia occurs as part of the syndrome of thyroid hypofunction in myxoedema or hypopituitarism. It was therefore decided to investigate thyroid function in patients with accidental hypothermia who were thought previously to have been euthyroid. The tests used were those indicating the amount of circulating thyroid hormone. The uptake by red cells in vitro of triiodothyronine labelled with radioactive iodine ${ }^{131} \mathrm{I}$ is directly proportional to the amount of thyroid hormone bound to plasma protein (Goolden et al., 1962). The serum protein-bound iodine (P.B.I.) is an accurate measure of circulating thyroxine.

Table II summarizes the results in 11 patients. In nine cases $\mathrm{T}_{3}$ uptake was in the hyperthyroid range, but in three of them the serum P.B.I. was at the same time in the hypothyroid range, and in one case where the $T_{3}$ was just above the normal range the serum P.B.I. was abnormally high. In only two patients was there an opportunity to repeat the investigation. In the first, with a high $\mathrm{T}_{3}$ and a low P.B.I., both results were in the normal range when repeated 10 days later. The other case showed a persistently high $\mathrm{T}_{3}$, but necropsy showed some hyperplasia of thyroid follicular epithelium. This patient died of carcinoma of the stomach, which might have given rise to a falsely high $\mathrm{T}_{3}$-uptake reading.

Although the $T_{3}$ readings might have suggested hyperfunction of the thyroid this was not confirmed by the P.B.I. results. One explanation for a false high reading in a $T_{3}$ uptake test is a low $p \mathrm{H}$ of the blood. Metabolic acidosis is known to occur in hypothermia induced for cardiac operations, and it is likely that the release of acid metabolites into a poorly oxygenated circulation which occurs in hypothermia could account for this. In one patient the $\mathrm{pH}$ of arterial blood within 24 hours of admission to hospital with a temperature of $75^{\circ} \mathrm{F}$. $\left(24.4^{\circ} \mathrm{C}\right.$.) was 7.275. The corresponding alkali reserve was normal, and this suggests that she had a metabolic acidosis. Respiratory acidosis might play a part where hypothermia is associated with depressed respiration or with severe bronchopneumonia, but no measurements of this were done in the present series. Another explanation is based on the finding that protein-binding of some drugs, including salicylates (Goolden et al., 1962), causes an apparently high uptake of $\mathrm{T}_{3}$ by the red cells. Since most of the patients were having antibiotics the possibility was considered that some antibiotics might also interfere with the binding of radioactive $\mathrm{T}_{3}$ in the plasma. In vitro evidence that penicillin interferes with the binding of thyroxine to plasma protein was demonstrated by Surks and Oppenheimer (1963). Our own preliminary observations have also indicated that the $\mathrm{T}_{3}$ uptake is higher when euthyroid patients are having penicillin than after the antibiotic is stopped.

TABLE II.-Thyroid Function in Accidental Hypothermia

\begin{tabular}{|c|c|c|c|c|c|c|c|c|}
\hline \multirow{2}{*}{ 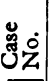 } & \multirow{2}{*}{ Age } & \multicolumn{2}{|c|}{ Temperature } & \multirow{2}{*}{ Diagnosis } & \multirow{2}{*}{ Outcome } & \multirow{2}{*}{$T_{3} *$} & \multirow{2}{*}{ P.B.I.t } & \multirow{2}{*}{ Remarks } \\
\hline & & ${ }^{\circ} \mathrm{F}$. & ${ }^{\circ} \mathrm{C}$. & & & & & \\
\hline 1 & 83\{ & $98 \cdot 4$ & $24 \cdot 4$ & $\begin{array}{l}\text { Confusion. } \\
\text { Mild C.V.A. }\end{array}$ & Recovered & $20 \cdot 7$ & 1.7 & $\begin{array}{l}\text { 2nd estimation } \\
\text { performed } \\
\text { several days } \\
\text { after recovery } \\
\text { from confu- } \\
\text { sional state }\end{array}$ \\
\hline 2 & 86 & 76 & $24 \cdot 4$ & $\begin{array}{l}\text { Fulminating } \\
\text { broncho- } \\
\text { pneumonia }\end{array}$ & $\begin{array}{l}\text { Died in } \\
24 \text { hours }\end{array}$ & $27 \cdot 5$ & - & $\begin{array}{l}\text { Serum amylase } \\
503 \text { units/ } \\
100 \mathrm{ml} \text {. }\end{array}$ \\
\hline 3 & 78 & 76 & $24 \cdot 4$ & $\begin{array}{l}\text { Broncho- } \\
\text { pneumonia. } \\
\text { Coronary } \\
\text { thrombosis }\end{array}$ & $\begin{array}{l}\text { Died in } \\
3 \text { days }\end{array}$ & $26 \cdot 3$ & $2 \cdot 0$ & Plasma $p H 7.28$ \\
\hline 4 & 81 & 82 & $27 \cdot 7$ & $\begin{array}{l}\text { Cerebral } \\
\text { haemorrhage }\end{array}$ & $\begin{array}{l}\text { Died in } \\
12 \text { hours }\end{array}$ & $20 \cdot 8$ & - & \\
\hline 5 & 82 & $82 \cdot 4$ & 28 & $\begin{array}{l}\text { Abscess of } \\
\text { kidney. Mild } \\
\text { diabetes }\end{array}$ & $\begin{array}{l}\text { Died in } \\
24 \text { hours }\end{array}$ & $39 \cdot 7$ & - & $\begin{array}{l}\text { P.M. - Nodu- } \\
\text { lar goitre, } \\
\text { acini dis- } \\
\text { tended with } \\
\text { colloid }\end{array}$ \\
\hline 6 & 89 & 85 & $29 \cdot 4$ & $\begin{array}{l}\text { Broncho- } \\
\text { pneumonia }\end{array}$ & $\begin{array}{l}\text { Initial } \\
\text { recovery, } \\
\text { died after } \\
5 \text { weeks }\end{array}$ & - & $3 \cdot 6$ & Euthyroid \\
\hline 7 & 87 & 85 & $29 \cdot 4$ & $\begin{array}{c}\text { Intracerebral } \\
\text { and subdural } \\
\text { haemorrhage }\end{array}$ & $\begin{array}{c}\text { Died in } \\
3 \text { days }\end{array}$ & $22 \cdot 7$ & $3 \cdot 8$ & $\begin{array}{l}\text { Semiconscious } \\
\text { for } 3 \text { days }\end{array}$ \\
\hline 8 & 78\{ & $98 \cdot 4$ & $31 \cdot 7$ & $\begin{array}{l}\text { Acute bron- } \\
\text { chitis. Ca. of } \\
\text { stomach. } \\
\text { Hb } 50 \%\end{array}$ & $\begin{array}{l}\text { Survived } \\
\text { for } 3 \\
\text { weeks }\end{array}$ & $29 \cdot 8$ & $4 \cdot 0$ & $\begin{array}{l}\text { P.M.-Colloid } \\
\text { hyperplasia of } \\
\text { right lobe of } \\
\text { thyroid. } \\
\text { Clinically } \\
\text { euthyroid }\end{array}$ \\
\hline 9 & 85 & 90 & $32 \cdot 2$ & $\begin{array}{l}\text { Broncho- } \\
\text { pneumonia. } \\
\text { Mild C.V.A. }\end{array}$ & $\begin{array}{l}\text { Died in } \\
5 \text { days }\end{array}$ & $20 \cdot 1$ & 8.9 & $\begin{array}{l}\text { P.M.-Thyroid } \\
\text { normal }\end{array}$ \\
\hline 10 & 87 & 94 & $34 \cdot 4$ & $\begin{array}{l}\text { Staphylococcal } \\
\text { pneumonia }\end{array}$ & $\begin{array}{l}\text { Survived } \\
10 \text { days }\end{array}$ & $21 \cdot 5$ & $1 \cdot 6$ & \\
\hline 11 & 82 & 94 & $34 \cdot 4$ & $\begin{array}{l}\text { Hypo- } \\
\text { glycaemia. } \\
\text { Myocardial } \\
\text { infarction }\end{array}$ & Recovered & $16 \cdot 7$ & $6 \cdot 0$ & $\begin{array}{l}\text { Diabetic with } \\
\text { overdose of } \\
\text { insulin zinc } \\
\text { suspension }\end{array}$ \\
\hline
\end{tabular}

* Normal range for uptake by red cells of ${ }^{131}$ I triiodothyronine $15-20 \%$.

+ Normal 3.5-7.5 $\mu \mathrm{g} . / 100 \mathrm{ml}$.

\section{Treatment and Outcome}

No active measures were taken to rewarm any of the patients, but they were left exposed at ward temperature. Hydrocortisone was administered intravenously in most cases, particularly when there was shock or stupor. The woman who recovered after a temperature of $76^{\circ} \mathrm{F}$. $\left(24.4^{\circ} \mathrm{C}\right.$.) received $800 \mathrm{mg}$. of hydrocortisone in the first 48 hours. Noradrenaline or mephentermine was used when the systolic blood-pressure was below $100 \mathrm{~mm}$. $\mathrm{Hg}$, with at least a temporary effect. As a fatal outcome was often associated with bronchopneumonia, high doses of antibiotics were given when infection was suspected, sometimes intravenously if the blood-pressure was low.

Four patients out of 32 survived and were discharged from hospital. Five of the remainder regained a normal temperature, but four of them died later from an underlying infection and one from carcinoma of the stomach. Table III shows the relationship between the degree of hypothermia and the associated clinical conditions.

\section{Discussion}

The occurrence of accidental hypothermia is related to several factors. The chief protective mechanisms for the maintenance 
TABLE III.-Association of Hypothermia, Clinical Diagnosis, and

\begin{tabular}{|c|c|c|c|c|c|}
\hline $\begin{array}{l}\text { Rectal } \\
\text { Tempera- } \\
\text { ture }\end{array}$ & $\begin{array}{c}\text { Clinical } \\
\text { Conditions }\end{array}$ & No. & $\begin{array}{l}\text { Death } \\
\text { in } \\
\text { Hypothermic } \\
\text { State }\end{array}$ & $\begin{array}{l}\text { Death after } \\
\text { Recovery of } \\
\text { Normal } \\
\text { Temperature }\end{array}$ & Recovery \\
\hline $\begin{array}{c}90-95^{\circ} \mathrm{F} . \\
(32 \cdot 2- \\
\left.35^{\circ} \mathrm{C} .\right)\end{array}$ & $\begin{array}{l}\text { Barbiturate poisoning } \\
\text { Myocardial infarct } \\
\text { Bronchopneumonia } \\
\text { Confusion + } \\
\text { chlorpromazine } \\
\text { Myxoedema }\end{array}$ & $\begin{array}{l}1 \\
2 \\
6 \\
1 \\
1\end{array}$ & $\begin{array}{l}1 \\
3 \\
1 \\
1\end{array}$ & 3 & $\begin{array}{l}1 \\
1\end{array}$ \\
\hline $\begin{array}{c}80-89^{\circ} \mathrm{F} . \\
(26 \cdot 7- \\
\left.31 \cdot 7^{\circ} \mathrm{C} .\right)\end{array}$ & $\begin{array}{l}\text { Acute confusion } \\
\text { Bronchopneumonia } \\
\text { Pulmonary abscess } \\
\text { Renal abscess } \\
\text { Cerebral haemorrhage } \\
\text { Coronary ischaemia } \\
\text { Dehydration } \\
\text { Myxoedema }\end{array}$ & $\begin{array}{l}1 \\
5 \\
1 \\
1 \\
4 \\
1 \\
1 \\
2\end{array}$ & $\begin{array}{l}3 \\
1 \\
1 \\
4 \\
1 \\
1 \\
1 \\
2\end{array}$ & $2^{*}$ & 1 \\
\hline $\begin{array}{c}\text { Below } \\
80^{\circ} \mathrm{F} . \\
\left(26 \cdot 7^{\circ}\right. \\
\text { C. })\end{array}$ & $\begin{array}{l}\text { Transient C.V.A. } \\
\text { Acute pancreatitis }+ \\
\text { coronary thrombosis } \\
\text { Bronchopneumonia } \\
\text { Fractured skull } \quad \text {. }\end{array}$ & $\begin{array}{l}1 \\
2 \\
1 \\
1\end{array}$ & $\begin{array}{l}2 \\
1 \\
1\end{array}$ & & 1 \\
\hline Total & & 32 & 23 & 5 & 4 \\
\hline
\end{tabular}

- Death several weeks after recovery of normal temperature.

of body temperature during exposure to a cold environment are through shivering and vasoconstriction of arterioles in the skin. In the series described in this paper all the elderly patients had a severe systemic illness, and one of the common consequences was immobility. When such patients were exposed in a cold room the amount of heat produced by shivering or retained by peripheral vasoconstriction was evidently inadequate to maintain normal body temperature. In the three patients with myxoedema there was a predisposition to the development of hypothermia, and this occurrence in August in one patient indicated that the primary disturbance was connected with the failure of thyroid function rather than the external environmental stress. Drugs which depress the mid-brain control of body temperature may cause or accelerate the development of hypothermia. In two cases chlorpromazine had been administered shortly beforehand. Hypothermia has also been reported as a result of the administration of imipramine ("tofranil ") (McGrath and Paley, 1960).

The state of unconsciousness itself depresses the protective mechanisms against loss of body heat, as was shown in dogs during and after light anaesthesia (Haterius and Maison, 1948). In patients with paraplegia the sympathetic dysfunction resulting in sluggish blood-flow and failure of vasoconstriction may further increase the loss of body heat. Below $90^{\circ} \mathrm{F}$. $\left(32.2^{\circ}\right.$ C.) shivering ceases and is replaced by rigidity of the muscles of an extrapyramidal type. A characteristic muscletremor pattern is usually seen on the E.C.G.

Cerebral depression is one of the consequences of the state of hypothermia (Lougheed, 1961). In some of the patients a transient cerebral vascular disturbance proceeded to a state of profound unconsciousness with severe hypothermia because of exposure to cold after a fall. As this could occur within a few hours it is recommended that routine inquiry should be made during the winter about the warmth of the body of any elderly person who is found lying unconscious, and the rectal temperature should be taken with a low-reading thermometer.

An equal distribution of infections among those with temperatures below and above $90^{\circ} \mathrm{F}$. $\left(32.2^{\circ} \mathrm{C}\right.$.) suggests that in many cases in this series hypothermia was a complication of a primary condition which caused death. Whether coronary thrombosis has led to the development of hypothermia in a collapsed patient or is a result of the circulatory changes in that condition may be difficult to establish. It has been shown experimentally (Cooper, 1961) that at $92^{\circ} \mathrm{F} .\left(33.3^{\circ} \mathrm{C}\right.$.) the coronary blood-flow in dogs is reduced by $50 \%$. There is an even greater fall in the cardiac output; haemoconcentration occurs as the temperature falls, and the risk of coronary thrombosis becomes greater. The association of multiple infarction of viscera with hypothermia has been pointed out by Duguid et al. (1961) and Read et al. (1961), and is thought to be due to thromboses occurring in the viscous blood. Pancreatitis varying in degree from fat-necrosis to acute haemorrhagic destruction of tissue was seen in several of the patients at necropsy, but the clinical indications were hardly noticeable. Mild resistance in the epigastrium and wincing of the stuporous patient were the two positive features noted and confirmed by a rise in the serum amylase. Acute pancreatitis was an early feature in those patients whose serum amylase was elevated, and it reverted to normal in some who had smallto-moderate rises.

No consistent abnormality in thyroid function was found in patients who were not thought to be myxoedematous. Verzár et al. (1953) found that in rats temperatures of $15^{\circ} \mathrm{C}$. inhibited the uptake of ${ }^{131} \mathrm{I}$. Between 23 and $28^{\circ} \mathrm{C}$. the uptake rate was slower, but the total amount was not different from that of controls, and in rats that had recovered from hypothermia ${ }^{131}$ I uptake was normal or slightly increased. Our results of the $T_{3}$ uptake by the red cells have shown that falsely high readings may be obtained in the hyperthyroid range, whereas the serum P.B.I. may be normal or low. This suggests that there is some interference with the binding of the radioactive $\mathrm{T}_{3}$ to the plasma proteins, and it is known that this can occur in acidosis, or with certain types of drug such as salicylates (Goolden and Osorio, 1962). Therefore in the investigation of thyroid function in these patients estimations of $\mathrm{T}_{3}$ uptake and P.B.I. should be done, and plasma $p \mathrm{H}$ and $\mathrm{PCO}_{2}$ levels should be known, in order to evaluate the results fully.

The difficulties in the management of patients with accidental hypothermia are reflected in the poor survival rates. Four patients survived in this series and five others recovered initially. Three out of 22 recovered completely in Duguid's series (temperatures below $90^{\circ}$ F.) and four others improved initially but died from pneumonia or cerebro-vascular accidents later. Although there are dangers stemming directly from prolonged deep hypothermia, active rewarming may produce a profound circulatory disturbance. This arises because of vasodilatation of skin vessels to which blood flows from the interior of the body. Since the temperature of the skin may be several degrees below that of the viscera, a further drop in the internal temperature may be induced with the risk of ventricular fibrillation. In the elderly, relapse into coma or confusion has been observed as the temperature was raised and the patient improved as it was allowed to fall again. Active rewarming may, however, be carried out when the temperature is above $90^{\circ} \mathrm{F} .\left(32.2^{\circ} \mathrm{C}\right.$.) and in acute hypothermia in a young person-for example, from exposure in water (Hardwick, 1962).

Other important measures have been stressed by Duguid et al. (1961). Thyroid hormone is justified only in myxoedema coma, and the consensus of opinion is that small doses should be used. The use of hydrocortisone is indicated on theoretical grounds in both myxoedema and accidental hypothermia, and was probably responsible for a successful outcome in a few cases of the present and other reported series.

\section{Summary}

Prolonged immobility and sometimes exposure to a cold environment were found to be predisposing causes of accidental hypothermia in a series of 32 elderly patients. Although severe systemic illness is usually a precipitating cause, a low body temperature may itself produce profound nervous and circulatory disturbances.

Common clinical conditions associated with accidental hypothermia in this series were bronchopneumonia and cerebrovascular accidents. Severe complications may be masked, and pancreatitis, detected in at least one-third of the patients, was suspected by slight rigidity and tenderness of the abdomen. 
Myocardial infarction and peripheral gangrene also occurred. The disturbance of consciousness is related to the degree of hypothermia.

At temperatures between 90 and $95^{\circ}$ F. $\left(32.2\right.$ and $35^{\circ}$ C.), if death occurred, the cause appeared to be the primary disease and not the hypothermia. The prognosis at temperatures below $90^{\circ} \mathrm{F}$. $\left(32.2^{\circ}\right.$ C.) was poor, and out of the 32 patients only four recovered completely. Four others, after an initial recovery, died later. High doses of intravenous hydrocortisone are recommended, particularly when consciousness is impaired.

In 11 of the patients in vitro tests of thyroid function were carried out. The red-cell uptake of ${ }^{131} \mathrm{I}$ triiodothyronine was in the hyperthyroid range in nine cases, but the serum P.B.I. was abnormally low in three of them. It is suggested that high results in the red-cell-uptake test may occur in accidental hypothermia because of the associated respiratory acidosis or metabolic acidosis. Antibiotics may also interfere with the tests. Several tests of thyroid function should be employed because various factors in hypothermia may interfere with individual tests.
We are grateful to our colleagues who referred to us some of the cases in this series, and we wish to thank Miss M. F. Crowley, of the Group Pathological Laboratory, for carrying out the biochemical investigations, and Miss H. Farran and Mrs. D Richardson, of New End Hospital, for the tests of thyroid function.

\section{REFERENCES}

Cooper, K. E. (1961). Brit. med. Bull., 17, 48

Duguid, H. Simpson, R. G. and Stowers, J. M. (1961). Lancet, 2, 1213. Emslie-Smith, D. (1958). Ibid., 2, 492.

Goolden, A. W. G., Gartside, J. M., Jackson, D. J., and Osorio, C. (1962). Ibid., 2, 218.

(1962), Ibid, 2, 936

Hardwick, R. G. (1962). Brit. med. Э., 1, 147.

Haterius, H. O., and Maison, G. L. (1948). Amer. F. Physiol., 152, 225. Lougheed, W. M. (1961). Brit. med. Bull., 17, 61.

McGrath, M. D., and Paley, R. G. (1960). Brit. med. 7., 2, 1364.

Osborne, J. J. (1953). Amer. F. Physiol., 175, 389.

Prescott, L. F., Peard, M. C., and Wallace, I. R. (1962). Brit. med. 3., 2, 1367.

Read, A. E., Emslie-Smith, D., Gough, K. R., and Holmes, R. (1961). Lancet, 2, 1219.

Surks, M. I., and Oppenheimer, J. H. (1963). Endocrinology, 72, 567.

Verzár, F., Vidovic, V., and Hajdukovic, S. (1953). F. Endocr., 10, 46

\title{
Accidental Hypothermia
}

\author{
MARTIN W. McNICOL*, M.B., M.R.C.P., ROGER SMITH*, M.D., M.R.C.P.
}

Brit. med.F., 1964, 1, 19-21

The very cold weather of early 1963 caused 15 patients to be admitted to the Central Middlesex Hospital with accidental hypothermia. This paper describes the clinical and laboratory findings. We made a special study of the respiratory function and acid-base balance.

\section{Clinical Aspects}

\section{Cases}

The main clinical features are shown in Table I. The ages of the patients ranged from 55 to 90 years. Most of them lived alone in unheated rooms, but some appeared to have adequate heating. The history was almost always one of progressive confusion ; slurring of speech, ataxia, and involuntary movements were common. These were followed by drowsiness and unconsciousness. The history was usually short, the patient passing into coma within three days, but in a few there had been progressive deterioration over a period longer than a week.

The clinical picture was constant and diagnostic. Shivering had stopped, the skin was icy cold to touch, and there was generalized muscular stiffness. The pulse rate was slow, and the blood-pressure tended to be low. Reflexes were depressed.

The diagnosis was easily confirmed with a low-reading thermometer and no special investigations were required. Difficulty arose only when an ordinary clinical thermometer was used. On clinical grounds it was not difficult to exclude the obvious causes of hypothermia, such as endocrine disease or overwhelming infection, but investigations did show several of its recognized complications: pancreatitis in Case 6 Read

- From the Central Middlesex Hospital, Park Royal, London.



